\title{
Postdigital Mediation of Transcendence
}

\author{
Eric Trozzo ${ }^{1}$ \\ Published online: 19 May 2020 \\ (C) Springer Nature Switzerland AG 2020
}

Keywords Icon and idol · Jean-Luc Marion · Cyber-theology · Digital religion · Theological aesthetics $\cdot$ Lutheran theology $\cdot$ Postdigital

\section{Art, Religious Excess, and the Postdigital}

A few years ago, I took my then-12-year-old son to an exhibit on the art of M.C. Escher. I was rather horrified when he immediately took my phone and began taking photos of the art. Why could he not be present in the moment and appreciate the art rather than take pictures to look at later? As he continued, however, I began to realize that this was his means of engaging with the art. It was the medium in which his relationship with the art was expressed. Rather than a divide of a subject viewing an object of art, the photograph was for him a manifestation of the interaction and interrelation of the two, even if he could not yet verbalize this understanding. In considering this experience, we find a variety of aspects of postdigital reality (Jandrić et al. 2018), including openings for the consideration of the religious in that reality.

In my son's capturing images of works of art, he was using the digital technology of my handheld device to rupture the subject/object divide. When he saw a piece of art that moved him, he would painstakingly set up his picture so that it captured his experience of that piece of art. He would then take a look at his picture and sometimes show me, and then move on, never to look at his photo again. This was intentional, as his photographing was not to preserve a memory but rather to enable his interaction with the art. He can still speak of small details in several of those art works. This digital device, then, on the one hand, helped mediate his encounter with the art. On the other hand, it did more than mediate; it became part of the encounter. The digital was itself integral to his encounter. It was a medium that was also a participant. It allowed a particular way for the encounter to be expressed, and the digital nature of the camera allowed this in a way that the time lag of traditional photography could not. The image itself was not the goal; rather, the goal was to process the inexpressible excess of an encounter with art. The action was intuitive on

Eric Trozzo

ejtrozzo@gmail.com

1 Australian Lutheran College, University of Divinity, Adelaide, Australia 
my son's part, but it represents an important theoretical shift. In this engagement, the divide between subject/object blurs. There is a mutual encounter. The destabilization of such a divide was anticipated by Wittgenstein's 'philosophy of the image' and poststructuralist inquiries into the nature of meaning (Naugle 2002). Yet, the digital image of the artwork brings a new dimension to encounter. The viewer is changed by the art; the art is viewed in a particular way in that encounter. The act of digitally capturing the image functions as a participant in the encounter that enables, records, and signifies the depths of meaning created in that moment. It allows the encounter to occur in a novel way.

The digital both mediates and is itself part of a postdigital experience. As the digital is more and more embedded in all encounters with the world, it not only becomes more hidden but also shapes interactions and thus becomes part of them. The experience and the medium cannot be separated. Together, they are able to produce a surplus or excess of meaning present in our engagement with the world. Such surplus can be called 'transcendence'; in theological thought, it represents the spiritual dimension of existence, or even the entanglement of the overflowing reality of the divine within the structures of the world. The recognition of such transcendence signifies an unspeakable or apophatic 'more' to existence. Such excess is not the negative or destructive surplus of fear, anxiety, and stress (which could be described through the theological metaphor of the 'demonic'), but rather a positive sense of overflow that leads to love of neighbour and an active hope in the realization of the good in the world.

\section{Mediation and Theology}

My own Lutheran Christian tradition has a long history of rumination on the nature of mediation within the spiritual encounter with the surplus meaning in human experience. For instance, the doctrine of incarnation pertains to speaking of the divine as mediated through the materiality of human life, and particularly the life of Jesus of Nazareth. Similarly, while my Lutheran Christian tradition is often understood as being textbased, I have suggested (Trozzo 2019) that the Lutheran understanding of the Word of God is actually better understood as addressing how the divine can be mediated through language - spoken and written - in a healing manner into human experience. Building from that, its sacramental tradition can then be seen as a further reflection on how mediating words of promise can be combined with material mediators - water, wine, and bread - to healingly address human experiences of guilt and shame through an encounter with the spiritual dimension.

While only a small part of my strand of Christian tradition, icons are an important aspect of some Christian spiritual traditions, especially the Orthodox tradition. French phenomenologist Jean-Luc Marion (1991) has built an important bridge into philosophy in this area in considering idols and icons in his argument for finding surplus meaning beyond a text. In his thought, icons and idols are not separate types of objects but rather different attitudes or manners of being in approaching phenomena. The idol is opaque: one's gaze stops at the object, beholding nothing more. Indeed, as the idol absorbs the gaze of the beholder it takes on a mirroring function. Thus, the encounter between a viewer and the idol is thought by the viewer to be a subject capturing an object in its sight, thereby marking a distinction between the two, but is in fact primarily a means of narcissistic self-projection. 
In distinction, the encounter with the icon is characterized by transparence. Marion argues, '[t] he icon does not result from a vision but provokes one ... [it] summons sight in letting the visible be saturated little by little with the invisible' (Marion 1991: 17). The icon provokes an engagement beyond that which it signifies. The image of the icon is not an object but a medium through which an engagement with deeper meaning is experienced. While the idol reduces to the self, the icon opens up an encounter with the Other that does not seek to subsume it. Marion uses this concept to deconstruct traditional notions of God as existing, while retaining a sense of the invisible sacred. I wish to highlight the role of the icon as a medium that also participates in a transforming interrelationship of human, medium, and the spiritual. Media is an everpresent and essential aspect of all phenomena and meaning-making.

Icons, I suggest, do not need to be limited to images, but rather can speak of a wide range of interactions with phenomena. Moreover, icons can occur through any media, including digital. Apophatic encounters with experiences of excess meaning such as joy, love, compassion, and wonder can be mediated through digital screens, for instance. This is not to say that all interactions masquerading as religious are true encounters with an icon. Many digital encounters that are designed to be specifically religious in fact function in a manipulative, self-serving, xenophobic, or narcissistic manner that promotes the idolatrous mode of engagement. Televangelists serve as a particularly crass example of this kind of idol. Nonetheless, a deeper type of encounter is possible. The digital camera was my son's medium in which his gaze upon the art transformed from idols to icons. The digital was not separate from this transformation, nor did it merely enable the transformation. It participated in the shifting of the gaze from idol to icon, even as its presence largely receded into the background of the experience.

Central to these various Christian theological ruminations on the mediation of the divine into human experience are the themes of healing and justice. The two are interrelated theologically. Human experiences of guilt, shame, self-centeredness, and fearfulness lead to actions characterized by greed, violence, and failure to act for the common good, and vice-versa in a vicious circle. The encounter with the divine is understood to be healing in addressing these negative tendencies and transformative in promoting positive engagements of compassion and seeking communal justice. The encounter with overflowing excess provokes an active political participation in seeking true justice and authentic peace, even as such aims do not conform to pre-determined political agenda. While in recent decades movements such as Latin American liberation theologies, African-American and South African Black theologies, and Korean Minjung theologies have sharpened, contextualized, and brought greater awareness to this political aspect of Christian theology (Barger 2018), it can be traced back along the margins of several Christian traditions, including the Lutheran one (DeJonge 2016).

\section{Postdigital Mediation}

The reason for bringing up these various strands of Christian thought on the mediation of the divine is to recognize that the Christian intellectual tradition has long engaged the question of the mediation of excess meaning, and so has strands of thought that can be useful, whether one is religious or not. Thought on postdigitalism is inevitably 
concerned to some degree with questions of how meaning is mediated in a world that is very much material while simultaneously saturated with the digital and unseen movements of information. How is meaning created, understood, and communicated in such an enmeshed situation? These questions echo some long-held discussions on the nature of revelation and the creation of meaning in theology and aesthetics, as demonstrated in Marion's discussion of icons (Potter 2018). I suggest, then, that scholars from these fields have valuable contributions to make in dialogue about postdigitalism. At the same time, as a Christian theologian, I recognize the tendency within Christian theology to being overly wedded to outdated framings of these reflections on mediation that ignore current movements of thought as well as the contemporary issues raised by digital technologies. Such intellectual conservatism too often leads to forms of political conservatism that ignore the contemporary requirements of seeking communal justice. In this way, it is important for theologians to be reading and engaging the full range of discourse around postdigital thought. Mutual dialogue, then, is vital.

My son has since become a serious amateur photographer. I have accepted that he engages the world in a postdigital manner I do not fully comprehend. He has his own camera now that he continually uses to draw out small details of the everyday life around us. He not only documents but truly participates in the world digitally, taking many photos and then uploading a few onto social media. He does this not to show off his life to others, but as a means of recognizing his own experiences, extending his self beyond his physical body onto the cloud. In this postdigital transcending of physical body, I suggest we can see a means through which a spiritual excess of meaning might be engaged.

\section{References}

Barger, L. (2018). The world come of age: an intellectual history of liberation theology. Oxford: Oxford University Press.

DeJonge, M. (2016). Martin Luther, Dietrich Bonhoeffer, and political theologies. In J. Barton (Ed.), Oxford research encyclopedia of religion. Oxford: Oxford University Press. https://doi.org/10.1093 /acrefore/9780199340378.013.307.

Jandrić, P., Knox, J., Besley, T., Ryberg, T., Suoranta, J., \& Hayes, S. (2018). Postdigital Science and Education. Educational Philosophy and Theory, 50(10), 893-899. https://doi.org/10.1080 /00131857.2018.1454000.

Marion, J. (1991). God without being: Hors texte. Trans. T. Carlson. Chicago, IL: University of Chicago Press. Naugle, D. (2002). Worldview: the history of a concept. Grand Rapids, MI: Eerdmans.

Potter, B. D. (2018). Image and kenosis: assessing Jean-Luc Marion's contribution to a post-metaphysical theological aesthetics. International Journal of Philosophy and Theology, 79(1-2), 60-79. https://doi. org/10.1080/21692327.2017.1372797.

Trozzo, E. (2019). The cyberdimension: a political theology of cyberspace and cybersecurity. Eugene, OR: Cascade. 